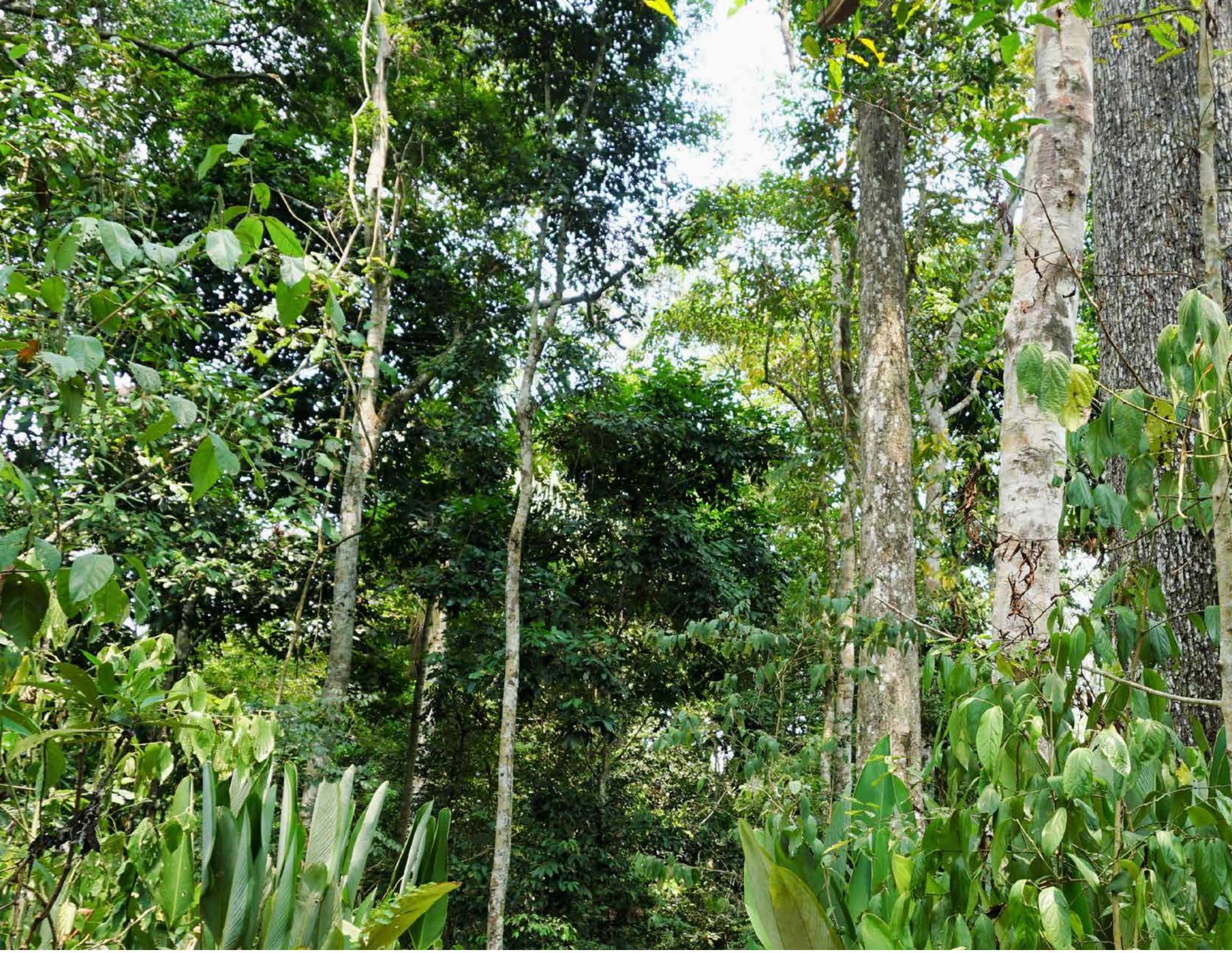

\title{
Practitioners Handbook on Good Practice in Implementing Forest Tenure Reform
}

Eric A. Coleman
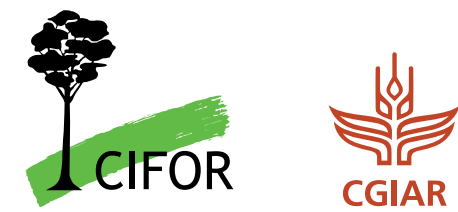



\section{Practitioners Handbook on Good Practice in Implementing Forest Tenure Reform}

Eric A. Coleman

Department of Political Science, Florida State University 
(C) 2019 Center for International Forestry Research

(c) (i) Content in this publication is licensed under a Creative Commons Attribution 4.0 International (CC BY 4.0), http://creativecommons.org/licenses/by/4.0/

DOI: $10.17528 /$ cifor/007503

Coleman EA. 2019. Practitioners Handbook on Good Practice in Implementing Forest Tenure Reform. Bogor, Indonesia: CIFOR.

Photo by Yoly Gutierrez/CIFOR

GCS REDD+

\section{CIFOR}

Jl. CIFOR, Situ Gede

Bogor Barat 16115

Indonesia

$\mathrm{T}+62(251) 8622-622$

F +62 (251) 8622-100

E cifor@cgiar.org

\section{cifor.org}

We would like to thank all funding partners who supported this research through their contributions to the CGIAR Fund. For a full list of the 'CGIAR Fund' funding partners please see: http://www.cgiar.org/our-funders/

Any views expressed in this publication are those of the authors. They do not necessarily represent the views of CIFOR, the editors, the authors' institutions, the financial sponsors or the reviewers. 


\section{Contents}

$\begin{array}{ll}\text { Acknowledgements } & \text { v }\end{array}$

1 Background 1

2 The political economy of policy reform implementation 3

2.1 Collaborative policy implementation 3

2.2 Ensuring women's participation and representation 4

3 Government perceptions $\quad 6$

3.1 Type of reform 6

3.2 Challenges of reform implementation $\quad 6$

4 Strategies for change $\quad 8$

4.1 Improve agency capacity $\quad 8$

4.2 Build local capacity 8

4.3 Obtain free prior and informed consent (FPIC) 9

4.4 Facilitate stakeholder engagement 9

4.5 Inclusion of women, minorities, and other socially disadvantaged groups 9

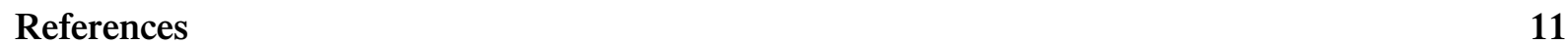




\section{List of figures, tables and boxes}

1 Types of forest tenure rights 2

2 Types of recent tenure reforms in the CIFOR Global Comparative Study Administrative Survey countries 


\section{Acknowledgements}

CIFOR's 'Global Comparative Study on Forest Tenure Reform' is funded by the European Commission and the Global Environmental Facility (GEF) with technical support from the International Fund for Agricultural Development (IFAD) and the United Nations Organization for Food and Agriculture (FAO). We would also like to thank FAO for helpful reviews and comments on an earlier version. This study forms part of the Program on Policies, Institutions and Markets (PIM), led by the International Food Policy Research Institute (IFPRI); and the CGIAR Research Program on Forest, Trees and Agroforestry (FTA), led by CIFOR. This handbook has not gone through IFPRI's standard peer-review procedure. The opinions expressed here represent the analysis of the authors and do not necessarily reflect those of PIM, IFPRI, CIFOR, CGIAR or the financial sponsors. 


\section{Background}

Many recent tenure reform policies strive to extend or solidify tenure security through the legal recognition of customary and local authorities, indigenous territorial rights and women's rights. This handbook is motivated by the problems that practitioners have on the ground when implementing these polices. Some of these problems are endemic to the political economy of policy implementation, while other problems might be ameliorated by increased capacity building and training. Of course, it is difficult to generalize across all potential contexts for a standardized approach to handle tenure reform implementation. On the other hand, implementers could benefit from a shared understanding of some of the most common problems and learn about approaches to handle them.

Land tenure is an institution, a set of rules used to structure human interactions with land (see Ostrom 2005). Land tenure institutions can be quite complex, with the state, individuals, and communities each holding some rights to use the resource in particular ways (Schlager and Ostrom 1992). Recent trends in natural resource tenure reform tend to allocate or affirm property rights to communities (pre-defined collectives of individuals). Reducing Emissions from Deforestation and forest Degradation (REDD+) has hastened the need to clarify these tenure arrangements, especially in relation to communities of forest users, in order to maintain incentives for resource conservation (Sunderlin et al. 2014).

Tenure security refers to the dependability of these property rights institutions. It reflects the expectations that property rights will exist and be effectively enforced in the future. When resource tenure is secure for a community, then the community has incentives to invest in maintaining the resource. ${ }^{1}$ However, if tenure is insecure, then communities have little incentive to make investments in the present, because of the uncertainty that returns from those investments will be realized in the future (Barzel 1997). Thus, a primary concern among those advocating more local control of natural resources is that polices not only establish or affirm rights to these communities, but that communities are secure in the knowledge that such rights will persist into the future; otherwise, there might be strong incentives for the communities to overexploit resources in the present.

Schlager and Ostrom (1992) offer a way to think about different types of tenure. They challenge us to think beyond the oversimplified, binary, view of whether or not a community has ownership. Instead, we need to think about what types of rights a community has over a resource and what types of rights they do not. For example, very few communities have the explicit right to sell forestland, but nonetheless have a variety of other rights to use some forest products. Practitioners need to think carefully about what types of rights are held by communities and what types of rights are retained by the state. Adding to this typology of tenure rights, the Rights and Resources Initiative (2012) has reviewed types of forest tenure systems globally. Table 1 lists categories of tenure rights and gives some examples of how this might be manifested on the ground.

Efforts of forest tenure reforms may not change each of the rights listed in Table 1. For example, communities may only retain access rights to enter a forest but not alienation rights to sell forest land. Yet the same community may have a more complete set of rights for fuelwood. Some types of rights may be retained entirely by the state. "Community tenure" refers to the sets of rights held by the community over particular forest resources. Tenure is said to be secure when the rights held by a community are seen as (a) legitimate (i.e. they are formally recognized in statutory law or customary understanding), (b) protected (i.e. have institutional backing from the state or customary authorities) and (c) clear in terms of the specificity of what bundle of rights are held by whom (Aggarwal and Elbow 2006; Meinzen-Dick et al. 2004; Lawry 1990).

1 Resource maintenance might come from investments to improve resource conditions (i.e. hiring a local forest guard or abstaining from overharvesting from the resource). 
Table 1. Types of forest tenure rights

\begin{tabular}{ll}
\hline Type of rights & Examples \\
\hline Access rights & People can freely enter the forest area. \\
\hline Withdrawal rights & $\begin{array}{l}\text { People can withdraw forest resources, but there may be limits on the } \\
\text { types/amounts of resources that may be withdrawn. }\end{array}$ \\
\hline Management rights & $\begin{array}{l}\text { People can make rules about how the forest may be accessed or how forest } \\
\text { resources may be withdrawn. }\end{array}$ \\
\hline Exclusion rights & $\begin{array}{l}\text { People can exclude other from accessing, withdrawing or participating in } \\
\text { forest management. }\end{array}$ \\
\hline Alienation rights & People can transfer their rights to someone else. \\
\hline Duration of rights & $\begin{array}{l}\text { People are confident that they will be able to continue to exercise their } \\
\text { rights in the future. }\end{array}$ \\
\hline Extinguishability of rights & $\begin{array}{l}\text { People can challenge state attempts to expropriate forestland for the } \\
\text { public good under notions of eminent domain. }\end{array}$ \\
\hline
\end{tabular}

While national policy can establish or affirm communal tenure of natural resources, the practitioners that implement such reforms have an important role in ensuring that such reforms secure the rights held by the community. Many problems face the officials who implement these policies on the ground. For example, in the forest sector, agency personnel often have strong scientific background in forest management, but have little training about how to navigate, much less establish, new social institutions. Some specific challenges they face, in many contexts, include:

- Political interference from national, regional and local governments

- Collaboration with other actors including other government agencies, donors, the non-profit sector, civil society organizations and traditional/customary authorities

- Working directly with communities, especially when there may be conflict within or between communities

- Difficulty engendering both descriptive and substantive participation by women and other marginalized groups

- Difficulty of harmonizing national tenure policy reforms with local customs and managing competing claims of tenure

- Identifying a common definition of terms (e.g. tenure security, representation) and a common understanding to recognize whether policy implementation is successful.

In the remainder of this handbook, we will outline the nature of these problems and the perceptions of agency personnel on the prevalence and importance of such issues, and then review some mitigation strategies. 


\section{The political economy of policy reform implementation}

Policy implementation is beset by a wide range of problems. In the classic model of bureaucratic implementation, an agency faithfully establishes rules that reflect the intentions of policies made by the executive or legislature. In reality, this is extremely difficult for a number of reasons (Balla and Gormley 2017): (1) often the intentions of policy are ambiguous; (2) there are normative concerns about whether agencies should be upwardly accountable to legislators or the executives, or downwardly accountable to citizens; (3) there are often conflicting mandates from different policies that agencies are tasked with implementing; (4) agencies must often use discretion to account for local context not anticipated during the creation of national policy reform; (5) agencies increasingly deal with demands from non-governmental organizations, civil society, donors and the private sector, and must decide how to balance these demands with those from citizens and superiors; and (6) agencies have limited resources (budgets, personnel and time) and capacity to carry out the reforms they are tasked with and therefore must prioritize some issues over others.

This fracturing of accountability among different actors pulls agencies in many different directions and complicates decision processes. Agencies must identify the actor(s) to whom they are primarily responsible for tenure reform implementation. This might be done by explicitly examining the statute authorizing reforms or by referencing the agency's overall mission. Usually there is some explicit reference of accountability to citizens and communities as a whole. There are sometimes conflicts of interest between different actors demanding attention. Agency personnel need to be mindful of the power deficits within communities and between communities and other actors. ${ }^{2}$

Starting in the 1980s and 1990s, central governments have increasingly recognized the role of communities in the ownership and management of forests, but during the ensuing years communities have struggled to obtain recognition of forest tenure (White and Martin 2002). Much of current tenure reform is taking place against the background of REDD+ (Sunderlin et al. 2014). Land tenure needs to be clarified to identify the beneficiaries of REDD+ payments and ensure the equitable application of policy in light of existing tenure claims; efforts to clarify tenure arrangements are often contentious, and many of the issues of tenure reform need to be addressed at national, regional and local scales. Practitioners are often beholden to the ambiguity in tenure as outlined in national policy and must cope with these ambiguities on the ground.

\subsection{Collaborative policy implementation}

Most natural resource management, including changes in tenure relationships, has witnessed a flood of policy innovations that can be broadly defined as collaborative governance (Lubell et al. 2010). Collaborative governance requires cooperation and collaboration from actors in the private sector, non-governmental organizations (NGOs), diverse government agencies, and central, regional and local government units. Collaborative governance seeks to build consensus and cooperation among diverse stakeholders who have political, economic or administrative stakes in policy outcomes. The broad structure of collaborative governance is composed of different actors (e.g. an agency or an NGO)

2 Often such power deficits are evident in the existence of socioeconomic differences between groups (e.g. gender division, ethnic groups, caste differences). Evidence suggests that minority groups may be systematically excluded from exercising their tenure rights (Coleman and Liebertz 2014). 
who participate in different policymaking forums (e.g. regional planning, tenure reform, agriculture extension). Thus, the complex governance networks consist of the mapping of actors and forums.

Natural resource management is a 'wicked' policy problem in terms of complexity, scale, and the number and diversity of actors involved (Weber and Khademian 2008). ${ }^{3}$ Collaborative governance as a solution to such wicked problems is especially important in contexts where the formal central state is too weak to effectively administer traditional regulatory programs itself (Donahue 2004). These two problem characteristics (complexity and a weak central state) are key constraints on effective tenure reform implementation. Complex policy networks are needed that incentivize cooperation and coordination among diverse stakeholders (Ostrom 1998). Traditional policy approaches with oversimplified prescriptions (e.g. decentralization, nationalization and privatization) are simply unable to effectively deal with the complex problems inherent in current natural resource management (Ostrom et al. 2007). Therefore, one key challenge that practitioners must grapple with is how to design and navigate complex collaborative governance institutions that engage diverse actors to participate and support tenure reform.

A number of observations emerge from the scientific literature on collaborative governance. First, actors that have strong, dense networks with others hold disproportionate influence in the governance system. Second, agencies from central governments are more likely to be important actors in these networks and thus hold disproportionate influence. Third, NGOs and the private sector have high rates of participation, while community groups are more limited. Much of this is driven by the scale of participation, where NGOs and the private sector often participate in many forums while communities participate only in close proximity to their direct interests. Fourth, actors balance the needs of achieving their preferred policy outputs in some forums by negotiating over issues within and between forums. Thus, actors might sacrifice achieving policy implementation according to their preferences in some forums in order to gain concessions on other issues, perhaps in other forums. Fifth, there is a trade-off between strong collaboration with few actors and broader, weaker collaboration with many actors. Empirical evidence shows that broad collaboration enables actors to achieve their preferred policy outputs in the forums most important to them (Mewhirter et al. 2019). For example, some actors may be willing to compromise on some aspects of tenure reform implementation in some venues if this is offset by concessions in other areas.

\subsection{Ensuring women's participation and representation}

There are two types of reasons to support expanding women's participation in forest management. First is the normative reason that having women participate in policy implementation is more normatively desirable and more democratic in and of itself. Second is the notion that women's participation is instrumental in achieving certain types of outcomes. In fact, there is increasing empirical support for the notion that when women participate in natural resource governance, outcomes from those institutions are more likely to reflect the preferences of women (Coleman and Mwangi 2013). ${ }^{4}$

\footnotetext{
3 Weber and Khademian (2008) define wicked problems as (1) unstructured, in that the causes and effects of problems are extremely difficult to identify, (2) comprised of multiple, overlapping, interconnected subsets of problems, and (3) relentless, in that they will not be solved once-and-for-all but rather require sustained attention.

4 When women participate in politics, decisions are more likely, on average, to reflect women's preferences (Wängnerud 2009). However, there is still debate in the literature about whether and how women's participation in natural resource governance might engender more sustainable resource management. Much of this stems from questionable assumptions about women having stronger preferences for specific types of conservation activities than men. Results from a CIFOR global comparative study question whether any general conclusion can be made about the systematic preferences of women in all contexts as being more sustainable than men's (Sunderland et al. 2014). Indeed, there are strong theoretical reasons to be skeptical of any general social or biological gender-specific predisposition towards conservation (Robbins 2012, 64).
} 
Women can participate in the management of natural resources directly, or indirectly by having political leaders represent their interests. Direct participation involves attending meetings or giving in-kind labor to support forest management institutions (e.g. tree planting or forest monitoring). Agarwal $(2001,2009)$ has done extensive research on the barriers to and effects of direct participation by women in natural resource management. She finds that local institutions often preclude women from participating in forest management. Even when women do participate in management, their preferences are often muted (i.e. they do not speak up) or they may be co-opted by patriarchal power structures. She finds that simply inviting women to participate in forest management does not improve policy decisions for women (Agarwal 2001). Thus, practitioners should be aware that simply having women attend meetings is likely insufficient. Only when women feel empowered to speak up and have their voice heard will direct participation be effective. Some practitioners have found that holding women-only meetings can be effective; others emphasize the importance of participatory processes that allow voice to diverse groups (Parker and Dakin 2008).

Less research documents the effects of indirect participation, through political representation, and on improving resource management. Scholars have distinguished between two types of representation more generally (Wängnerud 2009): descriptive representation refers to the number (or proportion) of women in decision-making bodies, while substantive representation refers to whether women's issues are addressed, regardless of the actual gender composition of the decision-making body. Evidence suggests that descriptive representation is a necessary condition for substantive representation (Phillips 1995). Community-based forest management user groups often have a board that determines rules and penalties; representation by women on these political bodies may help improve outcomes. 


\section{Government perceptions}

The preceding section identified many of the expected frictions to effective reform implementation. This section reviews the empirical results from a survey of 145 agency personnel involved in tenure reform implementation The survey is comprised of about 29 administrators in each of the following countries: Indonesia, Kenya, Nepal, Peru and Uganda. The survey was conducted as part of CIFOR's Global Comparative Study on Tenure Reform. While the survey is certainly not representative of all countries where forest tenure reform is taking place, it does provide some indication of the issues and priorities of administrators in these countries.

Table 2. Types of recent tenure reforms in the CIFOR Global Comparative Study Administrative Survey countries

\begin{tabular}{ll}
\hline Country & Type of reform \\
\hline Kenya & Community-based forest management \\
\hline Indonesia & Social forestry schemes (community access rights to state forests) \\
\hline Nepal & Community forestry \\
\hline Peru & Indigenous community land titling \\
\hline Uganda & $\begin{array}{l}\text { Formalizing community forests on customary lands (i.e. land registration), collaborative } \\
\text { forest management, private forestry }\end{array}$ \\
\hline
\end{tabular}

\subsection{Type of reform}

We start by examining the types of reforms being implemented in these countries. Around $95 \%$ of the respondents in the survey reported that they were engaged in community-based tenure reform proposals. This reflects the survey design because we were interested in communal tenure reforms. Two-thirds of the respondents (66\%) said the primary service they provided to the community was training on the new reforms (an additional $7 \%$ listed rights recognition, in a separate category). Two-thirds of the respondents (66\%) also indicated that the primary purpose of the reforms was to extend access rights to communities (e.g. establishing new tenure relationships) while another $20 \%$ indicated that the primary objective was to secure existing tenure rights. There was general optimism about whether the objectives of the reforms were achievable, with $96 \%$ of respondents indicating that establishing tenure was achievable and $90 \%$ indicating that securing tenure was achievable.

\subsection{Challenges of reform implementation}

The survey also included a question asking respondents to identify the general challenges they faced. The biggest constraint respondents identified was inadequate budgets to carry out the reforms (more than 70\% identified this as the most or second most important constraint). Administrators also identified lack of sufficient personnel as important. These were by far the most significant constraints, but they are also the most difficult for practitioners to unilaterally change. The other most frequently identified challenges had to do with lack of local capacity: insufficient local knowledge about rights and noncompliance by locals with changes in tenure structures. Therefore, implementers should seek to improve literacy on the legal rights and duties of communities and work with them to establish programs for monitoring reform implementation.

We also asked them about the specific challenges and consequences from implementing tenure reforms. These results demonstrated a great diversity of opinions about the challenges of reform. The most frequent mention was boundary conflicts between communities, although only $18 \%$ of 
respondents indicated that was the primary concern. Other frequent concerns spanned the list of possibilities from illegal timber harvesting (8\%) to conflicts with community rules (4\%) and customary laws (4\%). In short, the list of barriers to tenure reform implementation does not appear to be standard across contexts, and therefore priorities across contexts are difficult to establish. 


\section{Strategies for change}

In the previous sections, we identified many of the theoretical and empirical barriers to effective reform implementation. Unfortunately, it does not appear that the issues in tenure reform are consistent across contexts. However, some broad policy recommendations can be made to help practitioners identify and address specific problems as they arise. In this section, we list a variety of strategies that have been used to improve policy implementation and local participation in natural resource management in many contexts. The exact nature and applicability of each strategy will of course depend upon the capacity of the practitioners and the local context.

\subsection{Improve agency capacity}

Most practitioners in the forest sector have little background in the legal and social institutions of land tenure reform. Therefore, if possible, some training on the specific nature of the reforms as well as training in conflict management and community outreach is important. Also training on national and international laws/guidance on rights recognition will be beneficial (e.g. International Labour Organization Convention (ILO) 169 and the UN Declaration on the Rights of Indigenous Peoples 2007). If formal training opportunities are impossible, then mentoring could also be effective. A number of training manuals exist to provide guidance on mentoring programs for public administrators, and the resources outlined in Mayers et al. (2013, 104-107) might be particularly helpful. Uganda presents a successful example of building agency capacity during forest tenure reform efforts, where the survey indicates that "almost all respondents (97\%) had undertaken shortterm training in conservation, administration, community development, law, forestry, land and forest tenure, gender, GIS [Global Information System] and mapping, landscape design, project planning and management, conflict resolution, and financial management" (Nsita et al. 2017). While such efforts alone may not improve tenure security, they give necessary tools to agency personnel.

\subsection{Build local capacity}

Local capacity needs to be improved so that communities can participate throughout the policy process: during the formulation of implementation strategies, during implementation and when evaluating tenure reforms. Communities usually do not have the capacity to navigate new policy reforms and may be unfamiliar with the policy landscape and their rights within that landscape. Changes in forest tenure often have complex legal nuances or outright ambiguity. Additionally, some communities have more capacity for collective action than others for a variety of pre-existing reasons such as prior experience with policy reforms. The following is a list of items practitioners might do to improve community capacity:

- Meet with community members and/or leaders to provide information about policy changes and community rights. Often, the uncertainty of the new policy environment is the most concerning aspect to people. Simply knowing what the implications of the new policy are can begin to build trust between practitioners and the community.

- Make special efforts to include women, indigenous people, and other disadvantaged groups (e.g. low-income or ethnic minority) in these meetings and solicit feedback from these groups about their concerns.

- Collaboratively identify threats/potential threats to local tenure and new opportunities.

- Encourage community to identify and articulate priority areas. This will help practitioners focus on those problems most important for the community. Such a strategy can help practitioners justify future policy decisions. 
- Encourage the community to form formal forest user group associations if possible. Such organizations can provide a specific entity for practitioners to contact when issues arise and collaboration is needed.

\subsection{Obtain free prior and informed consent (FPIC)}

According to Mayers et al. (2013, 66-7): "FPIC means establishing the conditions under which people can and do exercise their right to negotiate the terms of externally imposed policies, programmes and activities that may affect the lands, resources or assets they customarily own, occupy or otherwise use, and give or withhold their consent to them." Many principles and guidelines exist to obtain FPIC from communities, and specific recommendations have been compiled in relationship to REDD+ projects (Anderson 2011): preparing rights holders to engage in FPIC (e.g. identifying rights and rights holders), implementing a process for respecting the right to FPIC (e.g. integrating FPIC into the project and ensuring independent advice) and maintaining consent (e.g. active monitoring and developing a grievance process).

\subsection{Facilitate stakeholder engagement}

Many different international organizations provide guidelines for stakeholder engagement. Among others, the International Finance Corporation (IFC) issues a handbook for stakeholder engagement, the United Nations has developed Guiding Principles on Business and Human Rights, and the European Commission has issued a guide on how to implement the UN Guiding Principles. Franks et al. (2014) report that most companies believe that conflict with local communities can be avoided by using best practices of stakeholder engagement. Stakeholder engagement is not new; it has become a primary tool of diverse policy formulation and implementation around the world. CIFOR recently developed a guide to facilitate stakeholder engagement for forest tenure security (Bourgeois et al. 2017).

There are many models of stakeholder engagement, although some of the most promising approaches involve multi-stakeholder forums wherein decision makers engage in collaborative planning processes with communities and representatives from the private and NGO sector (Edmunds and Wollenberg 2001; Coleman et al. 2019). Note that stakeholder engagement moves beyond mere token consultation; it instead demands a genuinely collaborative approach to policy implementation through sustained interactions. Some of the key features to ensure such collaboration are: (1) face-toface communication, which helps humanize the way actors are perceived; (2) strategic collaborations between communities and other actors to help countervail potential power asymmetries within multi-stakeholder forums; (3) timely consultation within the project planning cycle to ensure that community concerns can be addressed; (4) opportunities to make commitments to the community from other actors and opportunities for communities to reciprocate commitments; and (5) action plans by communities that provide guidance to follow-up on the commitments of others and hold them accountable for those commitments.

Building local capacity is a necessary precondition for effective multi-stakeholder collaboration. Communities do not usually have experience participating in these types of forums and may have diverse preferences about what they hope to get out of such interactions. Communities must first decide priority areas of concern, have appropriate expectations of outcomes from these interactions, and have an accurate understanding of their legal rights when engaging with other actors.

\subsection{Inclusion of women, minorities, and other socially disadvantaged groups}

Practitioners are obligated to promote gender representation and participation of indigenous communities, ethnic minorities and other groups that are frequently excluded from forest management. 
Establishment of tenure necessarily implies restricting access to some people to some uses of the resource. Practitioners should ensure that the burdens of such exclusions are not disproportionately born by certain groups. If land tenure reform establishes or reinforces private ownership, then practitioners should ensure that property rights are also available to members of vulnerable groups both in principle and in practice. If land tenure reform establishes communal institutions, then practitioners need to ensure that the uses of communal property do not exclude uses specific to these disadvantaged groups. For example, women often, although not always, use forest resources for subsistence uses and small-scale industry; community decisions to limit such activities may place a disproportionate burden upon them.

Forest tenure policies usually do not have enough force to change broader cultural norms related to these groups; however, practitioners should at least encourage the inclusion of vulnerable groups in decision-making as well as be aware of the practical implications and distributional effects of forest tenure reforms. The reader is referred to the technical guide developed by the FAO (2013) to promote gender inclusive land management practices. 


\section{References}

Agarwal B. 2001. Participatory exclusions, community forestry, and gender: An analysis for South Asia and a conceptual framework. World Development 29(10):1623-48.

Agarwal B. 2009. Gender and forest conservation: The impact of women's participation in community forest governance. Ecological Economics 68(11):2785-99.

Aggarwal S and Elbow K. 2006. The role of property rights in natural resource management, good governance and empowerment of the rural poor. Burlington, VT: ARD, Inc.

https://land-links.org/wp-content/uploads/2016/09/USAID_Land_Tenure_Property_Rights_and NRM_Report.pdf

Anderson P. 2011. Free, prior, and informed consent in REDD+: Principles and approaches for policy and project development. Bangkok and Eschborn, Germany: Regional Community Forestry Training Center (RECOFTC) and GIZ. http://www.recoftc.org/site/uploads/content/pdf/ FPICinREDDManual_127.pdf

Balla SJ and Gormley Jr. WT. 2017. Bureaucracy and Democracy: Accountability and Performance. Thousand Oaks, CA: CQ Press.

Barzel Y. 1997. Economic Analysis of Property Rights. Cambridge, UK: Cambridge University Press. Bourgeois R, Liswanti N, Mukasa C, Zamora A, Herawati T, Monterroso I, Mshale B, Banjade MR, Mwangi E and Larson A. 2017. Guide for Co-elaboration of Scenarios: Building Shared Understanding and Joint Action for Reform and Security of Forest Tenure. Bogor, Indonesia: Center for International Forestry Research (CIFOR). http://www.cifor.org/publications/pdf_files/ Books/BBourgeois1701.pdf

Coleman EA. and Liebertz S. 2014. Property rights and forest commons. Journal of Policy Analysis and Management 33(3):649-68.

Coleman EA, Manyindo J, Parker AR and Schultz W. 2019. Stakeholder Engagement Increases Transparency, Satisfaction, and Civic Action. Proceedings of the National Academy of Sciences 116(49):24486-24491.

Coleman EA and Mwangi E. 2013. Women's participation in forest management: A cross-country analysis. Global Environmental Change 23(1), 193-205.

Donahue JD. 2004. On Collaborative Governance. Cambridge, MA: Harvard.

Edmunds D and Wollenberg E. 2001. A strategic approach to multi-stakeholder negotiations. Development and Change 32(2):231-53.

Fernandini PW and Sousa RF. 2015. The distribution of powers and responsibilities affecting forests, land use, and REDD+ across levels and sectors in Peru: A legal study. Bogor, Indonesia: Center for International Forestry Research (CIFOR).

Food and Agriculture Organization of the United Nations. 2013. Governing Land for Women and Men: A Technical Guide to Support the Achievement of Responsible Gender-equitable Governance of Land Tenure. Rome, Italy: Food and Agriculture Organization (FAO).

Franks DM, Davis R, Bebbington AJ, Ali SH, Kemp D and Scurrah M. 2014. Conflict translates environmental and social risk into business costs. Proceedings of the National Academy of Sciences 111(21):7576-81.

Lawry SW. 1990. Tenure policy toward common property natural resources in sub-Saharan Africa. Natural Resources Journal 30(Spring):403-22.

Lubell M, Henry AD and McCoy M. 2010. Collaborative institutions in an ecology of games. American Journal of Political Science 54(2):287-300.

Mayers JEM, Rolington L, Studd K and Turrall S. 2013. Improving Governance of Forest Tenure: A Practical Guide. Rome: Food and Agriculture Organization of the United Nations.

Meinzen-Dick R, Pradhan R and Di Gregorio M. 2004. Collective action and property rights for sustainable development: Understanding property rights. Focus 2020, Brief 3. Washington, DC: International Food Policy Research Institute (IFPRI). 
http://lib.icimod.org/record/11703/files/4359.pdf

Mewhirter J, Coleman EA and Berardo R. 2019. Participation and political influence in complex governance systems. Policy Studies Journal 47(4):996-1019.

Nsita SA, Nakangu B, Banana AY, Mshale B, Mwangi E and Ojwang D. 2017. Forest tenure reform implementation in Uganda: Current challenges and future opportunities. CIFOR Infobrief 196. Bogor, Indonesia: Center for International Forestry Research (CIFOR).

Ostrom E. 1998. Scales, polycentricity, and incentives: Designing complexity to govern complexity. In Guruswamy LD and McNeely JA, eds. Protection of Global Biodiversity: Converging Strategies. Durham, NC: Duke University Press, 149-167.

Ostrom E. 2005. Understanding Institutional Diversity. Princeton, NJ: Princeton University Press.

Ostrom E, Janssen MA and Anderies JM. 2007. Going beyond panaceas. Proceedings of the National Academy of Sciences 104(39):15176-8.

Parker AR and Dakin R. 2008. Community-Company Assessment: A Guide for Practitioners. Rockville, MD: Business-Community Synergies.

Phillips A. 1995. The Politics of Presence. Oxford, UK: Oxford University Press

Robbins P. 2012. Political Ecology: A Critical Introduction, 2nd edition. Malden, MA: John Wiley \& Sons.

[RRI] Rights and Resources Initiative. 2012. What Rights? A Comparative Analysis of Developing Countries' National Legislation on Community and Indigenous Peoples' Forest Tenure Rights. Washington, DC: Rights and Resources Initiative.

Schlager E and Ostrom E. 1992. Property-rights regimes and natural resources: A conceptual analysis. Land Economics, 249-62.

Sunderland T, Achdiawan R, Angelsen A, Babigumira R, Ickowitz A, Paumgarten F, Reyes-García V and Shively G. 2014. Challenging perceptions about men, women, and forest product use: A global comparative study. World Development 64:S56-66.

Sunderlin WD, Larson AM, Duchelle AE, Resosudarmo IAP, Thu BH, Awono A and Dokken T. 2014. How are REDD+ proponents addressing tenure problems? Evidence from Brazil, Cameroon, Tanzania, Indonesia, and Vietnam. World Development 55:37-52.

United Nations (UN) General Assembly. 2007. United Nations Declaration on the Rights of Indigenous Peoples. New York: United Nations.

Wängnerud L. 2009. Women in parliaments: Descriptive and substantive representation. Annual Review of Political Science 12:51-69.

Weber EP and Khademian AM. 2008. Wicked problems, knowledge challenges, and collaborative capacity builders in network settings. Public Administration Review 68(2):334-49.

White A and Martin A. 2002. Who owns the world's forests? Forest tenure and public forests in transition. Washington, DC: Center for International Environmental Law. 

This short handbook outlines the nature of the problems faced by government agency personnel in the implementation of tenure reforms and is aimed at supporting their understanding of the issues and helping overcome challenges. It provides an introduction to key concepts and problems; discusses the results of a survey presenting the perceptions of government practitioners on the prevalence and importance of these issues; and proposes some mitigation strategies.

\begin{tabular}{|c|c|c|}
\hline CGIAR & $\begin{array}{l}\text { RESEARCH } \\
\text { PROGRAM ON } \\
\text { Policies, } \\
\text { Institutions, } \\
\text { and Markets } \\
\quad \text { Led by IFPRI }\end{array}$ & $\begin{array}{l}\text { The CGIAR Research Program on Policies, Institutions, and Markets (PIM) leads action-oriented research to } \\
\text { equip decisionmakers with the evidence required to develop food and agricultural policies that better serve } \\
\text { the interests of poor producers and consumers, both men and women. PIM combines the resources of CGIAR } \\
\text { centers and numerous international, regional, and national partners. The program is led by the International } \\
\text { Food Policy Research Institute (IFPRI). www.pim.cgiar.org }\end{array}$ \\
\hline
\end{tabular}

\begin{tabular}{|c|c|c|}
\hline (1) & $\begin{array}{l}\text { RESEARCH } \\
\text { PROGRAM ON } \\
\text { Forests, Trees and } \\
\text { Agroforestry }\end{array}$ & $\begin{array}{l}\text { This research was carried out by CIFOR as part of the CGIAR Research Program on Forests, Trees and } \\
\text { Agroforestry (FTA). FTA is the world's largest research for development program to enhance the role } \\
\text { of forests, trees and agroforestry in sustainable development and food security and to address climate } \\
\text { change. CIFOR leads FTA in partnership with Bioversity International, CATIE, CIRAD, INBAR, ICRAF and TBI. }\end{array}$ \\
\hline CGIAR & & FTA's work is supported by the CGIAR Trust Fund: cgiar.org/funders/ \\
\hline
\end{tabular}

CIFOR advances human well-being, equity and environmental integrity by conducting innovative research, developing partners' capacity, and actively engaging in dialogue with all stakeholders to inform policies and practices that affect forests and people. CIFOR is a CGIAR Research Center, and leads the CGIAR Research Program on Forests, Trees and Agroforestry (FTA). Our headquarters are in Bogor, Indonesia, with offices in Nairobi, Kenya; Yaounde, Cameroon; Lima, Peru and Bonn, Germany. 